\title{
A COMPREHENSIVE ANALYSIS OF THE RELATIONSHIP BETWEEN OFF-THE-JOB EMBEDDEDNESS AND CONTINUANCE COMMITMENT ON INTENTION TO STAY: BASED ON PLS-SEM
}

\author{
Ayesha Noor ${ }^{1, *}$ and Yuserrie Zainuddin ${ }^{1}$ \\ ${ }^{1}$ Faculty of Industrial Management, Universiti Malaysia Pahang, Malaysia
}

\begin{abstract}
Employee's Intention to Stay" as a term is broadly used in organization surroundings. The administrators must be identifying the importance of their staffs not only inspiring them to stay but also discourage them from seeking a better job to another place. Conversely, Job embeddedness is a construct which explains the reason for an individual's choice to stay or leave by considering the community and organizational forces that may retain employee on the workplace. Thus, the current study examined the relationship between off-the-job embeddedness, continuance commitment and employee's intention to stay using a sample of 177 employees of ICT industries. Simple Random probability sampling technique and partial least squares structural equation modelling (PLS-SEM) approach were employed to examine the relationship as drawn by the hypotheses. The findings of this paper discovered that there was a significant positive relation between fit and links dimension of off-the-job embeddedness, organizational continuance commitment and intention to stay. These outcomes suggest that organizations like the ICT industry (technology organization) need to consider off-the-job embeddedness relationships along with continuance organizational commitment when developing programs designed to affect the intention to stay decisions of members.
\end{abstract}

ARTICLE HISTORY

Received: 19-02-2019

Accepted: 04-05-2019

\section{KEYWORDS}

Off-the- Job Embeddedness, Continuance Commitment, Intention to Stay, PLS-SEM

\section{INTRODUCTION}

The importance of technology in our life is huge. In Malaysia, the Information and Communications Technology (ICT) mostly the usage of internet in online businesses is rapidly displacing the traditional method in carrying out businesses amidst mortal and brick establishments (Alias, Othman \& Loon, 2017). Due to the significance of the internet, a lot of establishments in Malaysia are converging towards the adoption of ICTs. The government of Malaysia has identified the ICT industry as a key economic area that possesses potentials in boosting productivity and raises the country's overall development. This has been initiated through the Eleventh Malaysia Plan (2016-2020) in which Malaysia was recognized as a high-income country (Koen, Asada, Nixon \& Rahuman, 2017).Therefore, this study centralized on the ICT industry as it has a greater impact i the Malaysian industrial sector. Besides this, the industry (ICT) may not be accomplishing their target growth due to a lack of skilled professionals. In Malaysian ICT industries, the turnover rate is often relatively high among certain groups of people's such as professionals (Noor, Zainuddin, Panigrahi, \& Rahim, 2018). From the last decade to recent, most of the industries are facing the issues related to employees leaving (Latif, Delaila, \& Saraih, 2016). According to the Malaysian employment statistics, the ICT industry showed a $23.1 \%$ turnover rate which was the highest of all the organizations in Malaysia (Radford, 2013-2016; Global salary increase and turnover, 2015). It shows that turnover has become a serious problem to the extent that the IT companies in Malaysia are facing the problem of retaining their skilled employees. So, it is essential for the IT companies in Malaysia to increase their current employees' intention to stay.

Moreover, it is questionable whether the high turnover of an employee at the ICT industry is due to external forces beyond the control of management or purely due to issues within a specific business unit. Therefore, to achieve an improved understanding of this phenomenon, the study on intention to stay in organization levels at a specific business unit called the ICT industry need to be investigated. This will give a better understanding of the employer on the root because that leads to high turnover among ICT employees. Even though many studies have covered the job embeddedness and the impact on organizational commitment, there is a gap of knowledge concerning employee intention to stay in the ICT industry. Additionally, little is known about how continuance commitment can be used as a strategic tool for an employee to stay in the ICT industry. Therefore, this study aimed to bridge this gap in knowledge. Hence, the objective of this study is to investigate the relationship between off-the-job embedddedness (fit community, links community, sacrifice community) and intention to stay on the ICT employee's. This paper also examines effect of organizational continuance commitment on employee's intention to stay. 


\section{LITERATURE REVIEW}

\section{Off- the- Job embeddedness}

Job embeddedness can be described in the form of a comprehensive assemblage of financial, social and psychological impacts on an employee's intention to stay (Mitchell, Holtom, Lee, Sablynski, \& Erez, 2001). In addition, job embeddedness comprises 3 components: sacrifice, fit and link. The dimension can be further grouped into community and organization according to whether the impacts exist off-the-job community or on-the-job organization (Dawley \& Andrews, 2012a).

Fit-Community: Physically powerful bond to members of a close extended family gives gratification to the inhabitants as a result of the needs-supplies (babysitting, family gatherings for holidays, dining, or birthday celebrations), thereby making members remain in the immediate geographical location. Certainly, the community-saved viewpoint of urban communities has been known to promote community fit such as inclusion, compatibility and belongingness (Treuren \& Fein, 2018)Therefore, this situation helps to establish employees or their close family members (children and spouses) in a community where they reside. Also, fit to community signifies worker's sensitivity of comfort with his or her environment. Workers are considering how effectively he or she fits into the surrounding and community. The community and environment can make individuals meaningful which will improve an individual's attachment to them ( Treuren, 2009). When the fit is better and the community is in comfort, it is highly possible that the employees would experience a relationship with the institutions that employed them. For example, May bank, an international bank in Malaysia, has decreased their turnover among personal bankers and customer service representatives by employing a large number of people that are living close to their branches (Halbesleben \& Wheeler, 2008). May bank had also improved their capability by providing services in the first language of Malaysian customers that frequently lived in the local populated communities. Furthermore, May bank had encouraged community activities by providing the employees with information about the communities including festival and processions. This participation has enhanced the integration of the employees into their communities. Likewise, it has enabled their customers to distinguish the significant differences between the larger national bank and their local bank (Afsar \& Ur Rehman, 2018).

Links community: Regular and strong quality relationship with loved ones (employee's parents and children's cousins) through the social exchange of valued resources, generates unbreakable bond or links. In fact, it is asserted by Conservation of Resources (COR) Theory that the motivation of people to continually increase their resources will make them desire to invest their resources in the most profitable place (Fasbender, Van der Heijden, \& Grimshaw, 2019). Close to family members is of great value to individuals (help with childcare and tasks), because they will always want to promote relationships in strengthen links in order to constantly receive more benefits including caring for elderly parents by the adult children ( Darrat, Amyx, \& Bennett, 2017). Additionally, a link to the community represents individuals' formal and informal relationships with their community. Mitchell \& Lee, (2001) reported that a volume of strand tied a worker and his families in the financial, psychological, and social web that includes non-work friends, groups, and community. When the number of relationship between the web and individual increases, the individual would become more tied to his/her organization and job.

Sacrifices community: Due to an excellent family bond that cannot be simulated easily from the community, supplies from the loved ones turn out to be sacrificed (Treuren \& Fein, 2018). This kind of non-transferable assistance from kinships (siblings lending emotional comfort during the divorce, retired parents who drive them to school) are important to the concerned persons to meet the requirements of the job so as to reduce any form of 'family-to-work' conflict. In addition, because persons are encouraged to protect the health and emotional well-being of their family members (children's health, spouse/partner's health), individuals may not want to relocate their loved ones so as not to forfeit the benefits derived from the family members (Ghosh \& Gurunathan, 2015).Moreover, community-related sacrifice represents perceived material and psychological benefits by being a member of the community that may be forfeited if one leaves a job or an organization. Respectful, safe and Leaving attractive communities can be a painful decision to take because it can result to severe loss of relationship with their comfortable and pleasant community and social support (Eady, 2014). Thus, when the sacrifices become higher the more, he/she will be bound to the firm.

\section{Continuance Commitment}

Organizational commitment used to be an important element in human resource and psychological studies. Continuance commitment is related with the understanding of the costs associated with leaving an organization. Employees who have a very strong continuance commitment would always stay due to the values they have added as an experienced employee in time past within the organization and not because they want to. Hence, understanding the relationships of the organizational continuance commitment to turnover is even more important. As such, this study focuses on continuance commitment.

The term "organizational continuance commitment" is used to explain an employee's continuance in an organization in a situation where it has become difficult for her/him to leave because of the investment accrued and sacrifices made while working for the organization (Vandenberghe, Panaccio, \& Ben Ayed, 2011). Additionally, organizational continuance commitment outlines the employees' possibility to use reliable tasks depending on their identification of the cost involved in the activity discontinuing. This can as well be referred to as calculative commitment which depends on the cost associated with an employee leaving an organization (Umoh, Amah, \& Wokocha, 2014). Continuance commitment can be regarded as a propensity used in techniques depending on the employee's perceived costs or profits linked with losses connected to leaving the cooperate firm (Khan, Naseem, \& Masood, 2019). Workers with a strong 
level of continuance commitments increase their strength on behalf of the firm because they think best their interest to do so.

\section{Intention to Stay}

Intent to stay is clearly elucidated as the employee's willingly to staying in his/her current job (Naim \& Lenka, 2017). The intent to remain in a job and earnings intent are employed interchangeably to measure the same intention though in differing ways (Halbesleben \& Wheeler, 2008). Nevertheless, the intent to remain on a job conveys optimistic connotation and mind set when it is corresponds to turnover intention. The positive construction is focused on (intention to stay) in this study. It is defined as an employer's retentive action with a purpose to persuade employees to stay with an establishment (Ngoc, Phuong, Chi, \& City, 2018) Furthermore, this can be described as the worker's intent to remain with an organization as a result of the conditions provided by the organization through intangible and tangible elements.

Previous studies showed how organizations looked at employee intention to stay, presented that organizations must balance the funds invested in employee's intention to stay as compared to the cost of replacement (Woon, Tan, \& Nasrudin, 2017). In addition, since it is extremely costly to replace highly regarded employees, organizations should consider investing in employee retention strategies. Employee intention to stay is the fundamental process by which organizations attempt to prevent their best employees from leaving. Retention strategies must be part of every aspect of operations because the intention to stay is vital to the organization's bottom line (AbuAlRub \& Nasrallah, 2017) . Aligning personal values and organizational duties can also help support employees' intention to stay. These and many other practical tools can be implemented to cause a positive influence on intention to stay in an industry. Organizations have now discovered the importance of having and retaining their workforce. Their focus has shifted to creating a conductive working environment which can facilitate workers' strong intention to remain on their job. Thus, employees' intention to stay has quickly become an integral part of an organization's total business strategies. Therefore, this study has discussed this concept as a main component of the study (Youcef, Ahmed, \& Ahmed, 2016).

\section{RESEARCH APPROACH}

\section{Survey design}

A self-administered questionnaire was used to collect data. Quantitative method was employed for this study. The research design used was descriptive and hypothesis testing and is cross-sectional in nature. Unit of analysis was individuals IT employees. Simple Random sampling technique was used in this study. The target population was employees of 1963 IT companies according to MSC 2018 that are operating in Malaysia. The list of IT companies had been taken from World Class Status listed by Multimedia Super Corridor (MSC). The sample size was determined by using Roscoe's (1975) rule of thumb. Roscoe states that this rule is appropriate for the study with a sample of more than 30 and less than 500. Moreover, Hair, Ringle \& Sarstedt (2011) stated that, for all multivariate study, the sample size must be several times (preferably 10 or more times) greater than a number of variable in the study. In total of 200 sets of survey questions were distributed to the ICT experts in Malaysia. PLS 3.0 were used to analyze the data. The oversampling helps to take care of the possible loss as a result of damages and non-cooperative subjects (Draugalis \& Plaza, 2009). Specifically, the oversampling was used so that the non-response rate and non-response bias will not have an influence on the result.

\section{Characteristics of Sample}

Sample comprise of 177 respondents as shown in Table 1. They are currently employed in various Malaysian ICT firms. ; $69 \%$ of the respondents are Malaysians. Among them 110 are male and 67 are female. In addition to the age group, about $53 \%$ of total sample is below 30 years. On the subject of the marital status, 77 participants as married and rest of 100 participants were single. Regarding academic qualification, 62\% participants have the bachelor degree. Furthermore, in case of job experience, 126 respondents were having 2-4 years of skill and around 50\% were junior executive position at their job place. The salary range of $46 \%$ respondent was RM2500 to RM 5000.

Table 1: Profile of Respondents

\begin{tabular}{|c|c|c|c|}
\hline & & Frequency & Percent (\%) \\
\hline \multirow[t]{2}{*}{ Gender } & Male & 110 & 62.1 \\
\hline & Female & 67 & 37.9 \\
\hline \multirow[t]{4}{*}{ Age } & Below 30 years & 94 & 53.1 \\
\hline & $31-35$ years & 56 & 31.6 \\
\hline & $36-40$ years & 24 & 13.6 \\
\hline & More than 40 years & 3 & 1.7 \\
\hline \multirow[t]{2}{*}{ Marital Status } & Single & 100 & 56.5 \\
\hline & Married & 77 & 43.5 \\
\hline \multirow[t]{3}{*}{ Ethnic Group } & Malay & 123 & 69.5 \\
\hline & Chinese & 22 & 12.4 \\
\hline & Indian & 29 & 16.4 \\
\hline
\end{tabular}




\begin{tabular}{llcc}
\hline & & Frequency & Percent (\%) \\
\hline \hline \multirow{3}{*}{ Education } & Others & 3 & 1.7 \\
& SPM & 2 & 1.1 \\
& SPTM & 4 & 2.3 \\
& Diploma & 43 & 24.3 \\
& Bachelor's & 110 & 62.1 \\
& Master Degree or higher & 18 & 10.2 \\
\multirow{3}{*}{ Job Position } & Non-Executive & 6 & 5.4 \\
& Junior Executive & 90.8 & 41.8 \\
& Senior Executive & 74 & 3.4 \\
Experience & Others & 6 & .6 \\
& Less than 1 year & 1 & 12.4 \\
& 2-4 years & 22 & 71.2 \\
& 5-7 years & 126 & 15.8 \\
& More Than 8 years & 28 & .6 \\
& Below RM 2500.00 & 1 & 36.2 \\
& RM 2500.00 to than RM 5000.00 & 64 & 46.9 \\
& RM 5000.00 to than RM 7500.00 & 83 & 15.3 \\
& RM 7500.00 & 27 & 1.7 \\
\hline
\end{tabular}

\section{DATA ANALYSIS AND RESULTS}

\section{Evaluation of Measurement Model}

The statistical software SmartPLS 3 and PLS-SEM technique was utilized to evaluate the hypothesized model(Hair, Sarstedt, Hopkins, \& Kuppelwieser, 2014). In order to sort measurement models, the study needs to influence the standard which had been suggested in the previous studies.

\section{Indicator Reliability and Convergent Validity}

This is related to a standard that the Cronbach's alpha coefficients of 0.60 have average reliability; however, it has an enormous reliability standard if the coefficient is equal or above 0.70 ( Ramayah et al., 2018). Also, Hair et al. concluded that a value of 0.70 or higher for the composite reliability coefficient(Hair et al., 2014). The instrument will share an enormous internal consistency and more reliable if the value is closer to 1 . Internal consistency reliability determines the level at which the sample measures the latent construct; it can be checked using the composite reliability (CR) scores. However, Fornell and Larcker provided that the Average Variance Extracted (AVE) score has to be 0.5 or higher (Fornell \& Larcker, 2006; PLS-SEM, 2015).

The results in table 2 exposed that present study Cronbach's alpha ranged from 0.71 to 0.91 and the CR scores of all constructs ( Continuance Commitment $=0.901$, Fit community $=0.903$, Intention to $\mathrm{Stay}=0.936$, Links Community $=0.916$ and Sacrifice Community=0.839) exceeded the recommended criterion of 0.7 demonstrating high internal consistency or the appropriateness of the scales used in this study (Avkiran, 2018). Next, factor loadings and average variance extracted (AVE) were assessed to determine the convergent validity of the constructs.

\section{Discriminant Validity}

Discriminant validity explains the degree at which a construct accurately different from others through the empirical standards (Hair et al., 2014; PLS-SEM, 2015). In this research, the discriminant validity was evaluated by utilizing three parameters such as HTMT. To achieve DV, the HTMT value needs to be higher compared to the HTMT.85 with a value of 0.85 (Henseler, Ringle, \& Sarstedt, 2014), or the HTMT.90 with a value of 0.90 (Carrión, Nitzl, \& Roldán, 2017). Based on the illustration in Table 3, all the obtained values are beyond both HTMT.90 and HTMT.85 measures, indicating that the discriminant validity had been created.

Table 2: Indicator Reliability and Convergent validity

\begin{tabular}{|c|c|c|c|c|c|}
\hline $\begin{array}{r}\text { Latent } \\
\text { Variables }\end{array}$ & Indicator & $\begin{array}{l}\text { Outer } \\
\text { /Factor } \\
\text { Loading } \\
\end{array}$ & $\begin{array}{l}\text { Cronbach's } \\
\text { Alpha }\end{array}$ & $\begin{array}{c}\text { Composite } \\
\text { Reliability }(\mathrm{CR})\end{array}$ & $\begin{array}{l}\text { Average Variance } \\
\left.\text { Extracted (AVE }{ }^{a}\right)\end{array}$ \\
\hline \multirow{6}{*}{$\begin{array}{l}\text { Continuance } \\
\text { Commitment }\end{array}$} & $\mathrm{CC} 2$ & 0.781 & \multirow{6}{*}{0.862} & \multirow{6}{*}{0.901} & \multirow{6}{*}{0.645} \\
\hline & $\mathrm{CC} 3$ & 0.799 & & & \\
\hline & $\mathrm{CC} 4$ & 0.810 & & & \\
\hline & CC5 & 0.775 & & & \\
\hline & CC6 & 0.848 & & & \\
\hline & $\mathrm{FC} 1$ & 0.711 & & & \\
\hline
\end{tabular}




\begin{tabular}{|c|c|c|c|c|c|}
\hline $\begin{array}{r}\text { Latent } \\
\text { Variables }\end{array}$ & Indicator & $\begin{array}{c}\text { Outer } \\
\text { /Factor } \\
\text { Loading }\end{array}$ & $\begin{array}{l}\text { Cronbach's } \\
\text { Alpha }\end{array}$ & $\begin{array}{r}\text { Composite } \\
\text { Reliability }(\mathbf{C R})\end{array}$ & $\begin{array}{l}\text { Average Variance } \\
\text { Extracted }\left(\mathrm{AVE}^{\mathrm{a})}\right.\end{array}$ \\
\hline \multirow{5}{*}{$\begin{array}{c}\text { Fit } \\
\text { community }\end{array}$} & $\mathrm{FC} 2$ & 0.881 & 0.866 & 0.903 & 0.652 \\
\hline & FC3 & 0.803 & & & \\
\hline & $\mathrm{FC} 4$ & 0.795 & & & \\
\hline & FC5 & 0.839 & & & \\
\hline & IN1 & 0.831 & & & \\
\hline \multirow{5}{*}{$\begin{array}{l}\text { Intention to } \\
\text { Stay }\end{array}$} & IN2 & 0.812 & & & \\
\hline & IN3 & 0.862 & 0.918 & 0.936 & 0.711 \\
\hline & IN4 & 0.886 & & & \\
\hline & IN5 & 0.791 & & & \\
\hline & IN6 & 0.873 & & & \\
\hline \multirow{6}{*}{$\begin{array}{c}\text { Links } \\
\text { Community }\end{array}$} & LC1 & 0.772 & & & \\
\hline & $\mathrm{LC} 2$ & 0.850 & 0.889 & 0.916 & 0.645 \\
\hline & LC3 & 0.788 & & & \\
\hline & $\mathrm{LC} 4$ & 0.828 & & & \\
\hline & LC5 & 0.816 & & & \\
\hline & LC6 & 0.759 & & & \\
\hline \multirow{3}{*}{$\begin{array}{r}\text { Sacrifice } \\
\text { Community }\end{array}$} & $\mathrm{SC} 1$ & 0.787 & & & \\
\hline & $\mathrm{SC} 2$ & 0.833 & 0.712 & 0.839 & 0.635 \\
\hline & $\mathrm{SC} 3$ & 0.768 & & & \\
\hline
\end{tabular}

Table 3: Discriminant validity results based on HTMT ratio of correlations (HTMT)

\begin{tabular}{llllll}
\hline Variables & CC & FC & INT & LC & SC \\
\hline \hline Continuance Commitment & & & & & \\
Fit Community & 0.660 & & & & \\
Intention to Stay & 0.669 & 0.764 & & & \\
Links Community & 0.589 & 0.678 & 0.675 & & \\
Sacrifice Community & 0.462 & 0.547 & 0.535 & 0.539 & \\
\hline
\end{tabular}

\section{Collinearity Statistics (VIF)}

Multicollinearity can be defined as the level to which a factor is defined through the other factors within the analysis (Hair et al., 2006). Due to the collinearity, it is strenuous to establish the impact of any single factor. This study employed variance inflation factors (VIF) to determine the multicollinearity. It should be noted that the VIF value above 5, shows multicollinearity (Hair et al., 2014). As presented in Table 4, the values of VIF were lower than the set criteria, indicating no multicollinearity issue.

Table 4: Collinearity Values among Exogenous Constructs

\begin{tabular}{lcc}
\hline Exogenous Constructs & Endogenous constructs & VIF \\
\hline \hline Fit Community & & 1.655 \\
Links Community & Continuance Commitment & 1.649 \\
Sacrifice Community & & 1.306 \\
Fit Community & & 1.910 \\
Links Community & Intention to Stay & 1.746 \\
Sacrifice Community & & 1.320 \\
Continuance Commitment & & 1.639 \\
\hline
\end{tabular}




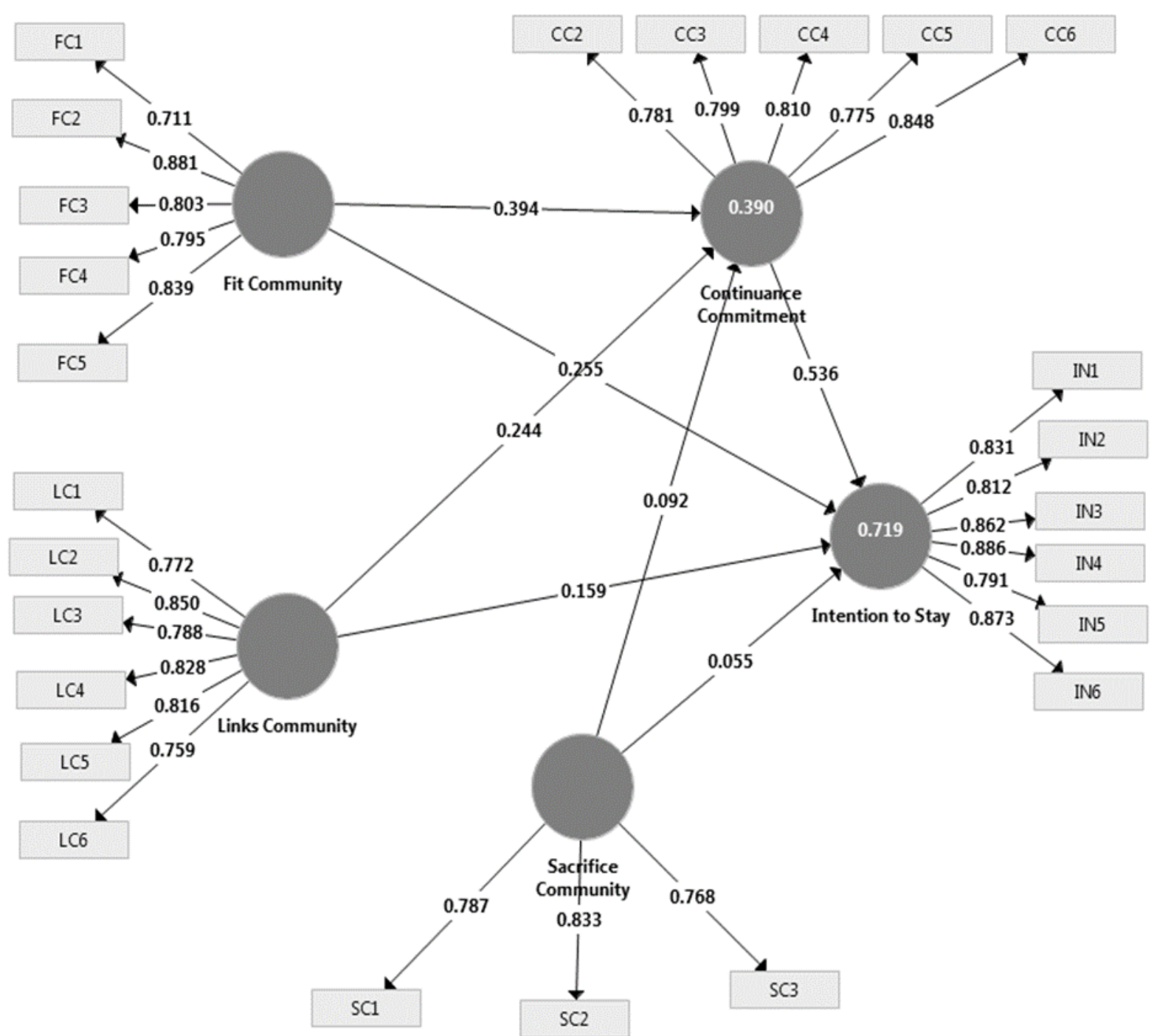

Note: $\mathrm{FC}=$ Fit Community, $\mathrm{LC}=$ Links Community, $\mathrm{SC}=$ Sacrifice Community, $\mathrm{CC}=$ Continuance Commitment, IN= Intention to Stay.

Figure 1: Measurement Model

\section{Evaluation of Structural Model}

Structural model was assessed to test the causal relationships between off-the-job (fit community, links community, sacrifice community) embeddedness, continuance commitment and intention to stay. The relationship between off-thejob embeddedness and intention to stay; fit community H1a $(\beta=0.255$, $\mathrm{t}=3.725)$, links community $\mathrm{H} 1 \mathrm{~b}(\beta=0.159, \mathrm{t}=2.806)$ was significantly influence on intention to stay but sacrifice community $\mathrm{H} 1 \mathrm{c}(\beta=0.055, \mathrm{t}=1.065)$ was in significant. On the other hand, relationship between continuance commitment and intention to stay $\mathrm{H} 2(B=0.536, t=7.341)$ was significant. Likewise, the relationship between off- the- job embeddedness and continuance commitment; fit community H3a $(\beta=0.394, t=4.432)$, links community H3b $(\beta=0.244, t=3.243)$ significantly influence on continuance commitment but sacrifice community $\mathrm{H} 3 \mathrm{c}(\beta=0.092, \mathrm{t}=1.267)$ was not significant. It shows that sacrifice community has no influence on both relationships.

The result from table 5 showed that hypothesis $\mathrm{H1}$ ( $\mathrm{H} 1 \mathrm{a}$ and $\mathrm{H} 1 \mathrm{~b}$ ) fit community and links community has a significant and positive influence on intention to stay, but hypothesis H1c sacrifice community was found to be positive but has an insignificant influence with intention to stay. As such, the result seems to have minimal impact on relationship between sacrifice community and intention to stay. On the other hand, $\mathrm{H} 2$ continuance commitment has a progressive relationship with intention to stay. Thus the hypothesis is accepted. In addition to hypothesis H3a and H3b, significant and positive relationship was found between fit community and links community with intention to stay, but for $\mathrm{H} 3 \mathrm{c}$ sacrifice community, it was found not to be insignificant. Off-the-job embeddedness comprised of three proportions; fit community, link community and sacrifice community which usually influences both the work and family life of a worker. Therefore, it is very clear that the person who has high off-the-job embeddedness will have less chance to quit the organization due to the feeling of being more attached. The results showed that two dimension of off-the- job embeddedness positively significant relationship with intention to stay at ICT industries Malaysia. 
Table 5: Results of Hypothesis Testing

\begin{tabular}{|c|c|c|c|c|c|}
\hline Hypothesis & Path & $\begin{array}{l}\text { Regression } \\
\text { Weight }\end{array}$ & $\begin{array}{c}\text { T- } \\
\text { Satistic }\end{array}$ & $\begin{array}{r}P- \\
\text { value }\end{array}$ & Remarks \\
\hline$\overline{\mathrm{H}_{1 \mathrm{a}}}$ & Fit Community -> Intention to Stay & 0.255 & 3.725 & $0.000 *$ & Supported \\
\hline $\mathrm{H}_{1 \mathrm{~b}}$ & $\begin{array}{l}\text { Links Community -> Intention to } \\
\text { Stay }\end{array}$ & 0.159 & 2.806 & $0.005^{*}$ & Supported \\
\hline $\mathrm{H}_{1 \mathrm{c}}$ & $\begin{array}{l}\text { Sacrifice Community -> Intention } \\
\text { to Stay }\end{array}$ & 0.055 & 1.065 & 0.287 & $\begin{array}{c}\text { Not } \\
\text { Supported }\end{array}$ \\
\hline $\mathrm{H}_{2}$ & $\begin{array}{l}\text { Continuance Commitment -> } \\
\text { Intention to Stay }\end{array}$ & 0.536 & 7.341 & $0.000 *$ & Supported \\
\hline $\mathrm{H}_{3 \mathrm{a}}$ & $\begin{array}{l}\text { Fit Community }->\text { Continuance } \\
\text { Commitment }\end{array}$ & 0.394 & 4.432 & $0.000 *$ & Supported \\
\hline $\mathrm{H}_{3 b}$ & $\begin{array}{l}\text { Links Community -> Continuance } \\
\text { Commitment }\end{array}$ & 0.244 & 3.243 & $0.001 *$ & Supported \\
\hline $\mathrm{H}_{3 \mathrm{c}}$ & $\begin{array}{l}\text { Sacrifice Community -> } \\
\text { Continuance Commitment }\end{array}$ & 0.092 & 1.267 & 0.206 & $\begin{array}{c}\text { Not } \\
\text { Supported }\end{array}$ \\
\hline
\end{tabular}

\section{Determination of Co-efficient (R2), Effect size (f2) and Predictive Relevance (Q2)}

$\mathrm{R}^{2}$ values of $0.19,0.33$ and 0.67 for endogenous latent construct within the internal model is presented as weak, moderate or substantial, accordingly (Chin, 1998). Table: 6 indicate a moderate model with $\mathrm{R} 2=0.390$ or $39.0 \%$ of the variance in continuance commitment. Similarly, the R2 value for intention to stay 0.719 or $71.9 \%$, of the variance interpreted as substantial model. Following performing blindfolding procedures, $\mathrm{Q}^{2}$ of continuance commitment $=0.225$ and intention to stay $=0.471$, which is larger than 0 , suggests that all endogenous construct predictive capacity over the exogenous constructs. In addition to Effects size (f 2) values; there is a large effect of continuance commitment (f2 $=0.625)$ on intention to stay. Besides this, off-the-job embeddedness; fit community ( $f 2=0.154$ ) had medium, links community (f2=0.059) and sacrifice community (f2=0.011) had small effect sizes on continuance commitment. Similarly, fit community ( $\mathrm{f} 2=0.121$ ), also had medium effect on intention to stay while links community (f2 $=0.052$ ) and sacrifice community (f2=0.008) had small effect on intention to stay.

Table 6: Results of $\mathrm{R}^{2}, \mathrm{Q}^{2}$ and $\mathrm{f}^{2}$

\begin{tabular}{|c|c|c|c|c|c|c|}
\hline & \multirow{2}{*}{$\begin{array}{l}\text { Determination } \\
\text { Co-efficient } \\
\qquad \boldsymbol{R}^{2}\end{array}$} & \multirow{2}{*}{$\begin{array}{c}\begin{array}{c}\text { Predictive } \\
\text { Relevance }\end{array} \\
\qquad Q^{2}\end{array}$} & \multicolumn{4}{|c|}{ Effect Size $\mathbf{f}^{2}$} \\
\hline & & & $\begin{array}{l}\text { Continuance } \\
\text { Commitment }\end{array}$ & $\begin{array}{l}\text { Effect } \\
\text { Size }\end{array}$ & $\begin{array}{c}\text { Intention } \\
\text { to Stay }\end{array}$ & $\begin{array}{l}\text { Effect } \\
\text { Size }\end{array}$ \\
\hline $\begin{array}{l}\text { Continuance } \\
\text { Commitment }\end{array}$ & 0.390 & 0.225 & & & 0.625 & Large \\
\hline $\begin{array}{l}\text { Intention to } \\
\text { Stay }\end{array}$ & 0.719 & 0.471 & & & & \\
\hline $\begin{array}{c}\text { Fit } \\
\text { Community }\end{array}$ & & & 0.154 & Medium & 0.121 & Medium \\
\hline $\begin{array}{c}\text { Links } \\
\text { Community }\end{array}$ & & & 0.059 & Small & 0.052 & Small \\
\hline $\begin{array}{l}\text { Sacrifice } \\
\text { Community }\end{array}$ & & & 0.011 & Small & 0.008 & Small \\
\hline
\end{tabular}

\section{DISCUSSION}

In this study, we found off-the-job embeddedness and their relationship with employee intention to stay and continuance commitment was proposed to be the mechanism that can explain those relationships in a clearer way. In other words, continuance commitment as an outstanding practice may help organizations to achieve the best results in controlling the performance of ICT employee's and increase the influential reasons that make people stay. The inconsistent findings of these relationships need further study to solve the issues. (Lee, Burch, \& Mitchell, 2014; Lee, Mitchell, Sablynski, Burton, \& Holtom, 2004; Naim \& Lenka, 2017). Although, there is a comprehensive review of literature which disclosed the fact but for in Malaysian background this topic of study is smallest amount. Therefore, present study measured off-the job embeddedness is a proper framework in Malaysian context. The findings of this research emphasized the importance of further deep study on these issues.

The relationship between off-the-job embeddedness and intention to stay among ICT professional in Malaysia is the main focus of this study. Off-the-job embeddedness comprised of three dimensions; fit community, link community and 
sacrifice community in which two dimension have significant relationships. Moreover, the result confirmed that, fit community and links community has positive significant relationship with intention to stay and sacrifice community has also positive but insignificant relationship with intent to stay. This finding is in line with previous studies that found that people who have more attraction towards the job sacrifice are more side with organizational objectives Omar et al., 2018; Dawley \& Andrews, 2012). Moreover, we found no evidence that observation of sacrifice attached employees to their communities. For these employees, their connection to the community was unrelated to the opportunity cost - the sacrifice - of leaving. It is another indirect argument that in our study majority of participants had these attributes; less years of experience, young and unmarried (approximately 56\%). Results indicated that continuance commitment has a straight connection with intention to stay in ICT industries in Malaysia. Naim \& Lenka, 2016 reported that continuance commitment gives a significant mediating role in positive relationship empowerment. In total the results not only supported previous outcomes that persons who were more embedded in their jobs had more chance to stay, but also expanded the significance of off-the-job and non- affective reasons of staying job. These findings suggest that organizations like ICT industry (technology organization) need to consider community/off-the-job embeddedness relationships along with continuance commitment when developing programs designed to affect intention to stay decisions of members.

\section{CONCLUSION}

Despite the considerable research on employee intention to stay, there is a research gap in linking these to off-the-job ( fit community, links community, sacrifice community)and relationship of continuance commitment. This gap thereby limits our understanding of the possible reasons of employee intention to stay in the field of ICT industry. Findings reveal that fit and links component of off-the-job embeddedness are positively significant relationship with employee intention to stay. Moreover, through off- the- job embeddedness accounting for all the additional certainty originally recognized to the job embeddedness concept, it can be implied that non- work, community based factors ( friends,family, relationships, etc.) play a significant role in a empoyee's intention to quit the job. It can be oblique from these outcomes that organizations should inspire and support participation in the community to help decrease employees losses.

\section{RESEARCH IMPLICATIONS}

In general, this study has added new valuable knowledge that can be utilized to produce organizational retention techniques in IT services work setting in Malaysia. The results have shown that an employee who has continuance commitment can significantly affect his/her perceived work embeddedness and vice versa. Moreover, the results highlighted that ICT employees are practical in establishing their link and fit in their communities and organizations. The literature reviews on job embeddedness have yet to study the function played by the employee rather than the employer capability in cultivating attachment. A study in the area of proactive has reported that when newcomers actively participated in proactive socialization behaviour, they would be more likely to see themselves as part of the majority. When the newcomers are part of the majority, it increases their chances to mix other persons in order to give their own positive contributions to the organization.

\section{ACKNOWLEDGEMENT}

Authors would like to acknowledge University Malaysia Pahang, Malaysia for providing financial support through the project GRS130371.

\section{REFERENCES}

AbuAlRub, R. F., \& Nasrallah, M. A. (2017). Leadership behaviours, organizational culture and intention to stay amongst Jordanian nurses. International Nursing Review, 64(4), 520-527. https://doi.org/10.1111/inr.12368

Afsar, B., \& Ur Rehman, Z. (2018). Relationship between Work-Family Conflict, Job Embeddedness, Workplace Flexibility, and Turnover Intentions. Hubs-Asia, 21(2), 92. https://doi.org/10.7454/mssh.v21i2.740

Alias, N. E., Othman, R., Loon, K. W., Ridzuan, A. R., \& Krishnan, R. (2017). Towards Effective Employee Retention Strategy: Implementation of Talent Management in Information, Communication and Technology Companies. Advanced Science Letters, 23(8), 7857-7860.

Avkiran, N. K. (2018). An in-depth discussion and illustration of partial least squares structural equation modeling in health care. Health Care Management Science, 21(3), 401-408. https://doi.org/10.1007/s10729-017-9393-7

Carrión, G. C., Nitzl, C., \& Roldán, J. L. (2017). Mediation analyses in partial least squares structural equation modeling: Guidelines and empirical examples. In Partial Least Squares Path Modeling: Basic Concepts, Methodological Issues and Applications (pp. 173-195). https://doi.org/10.1007/978-3-319-64069-3_8

Chin, W. (1998). Commentary: Issues and opinion on structural equation modeling.

Darrat, M. A., Amyx, D. A., \& Bennett, R. J. (2017). Examining the impact of job embeddedness on salesperson deviance: The moderating role of job satisfaction. Industrial Marketing Management, 63, 158-166. https://doi.org/10.1016/J.INDMARMAN.2016.10.012 
Dawley, D. D., \& Andrews, M. C. (2012a). Staying put: Off-the-job embeddedness as a moderator of the relationship between on-the-job embeddedness and turnover intentions. Journal of Leadership and Organizational Studies, 19(4), 477-485. https://doi.org/10.1177/1548051812448822

Draugalis, J. R., \& Plaza, C. M. (2009). Best Practices for Survey Research Reports Revisited: Implications of Target Population, Probability Sampling, and Response Rate. American Journal of Pharmaceutical Education, 73(8), 142. https://doi.org/10.5688/aj7308142

Eady, L. (2014). Job embeddedness and intention of voluntary turnover in the aerospace and defense industry: A quantitative study. ProQuest Dissertations and Theses, (June), 145.

Fasbender, U., Van der Heijden, B. I. J. M., \& Grimshaw, S. (2019). Job satisfaction, job stress and nurses' turnover intentions: The moderating roles of on-the-job and off-the-job embeddedness. Journal of Advanced Nursing, 75(2), 327-337. https://doi.org/10.1111/jan.13842

Fornell, C., \& Larcker, D. F. (2006). Structural Equation Models with Unobservable Variables and Measurement Error: Algebra and Statistics. Journal of Marketing Research, 18(3), 382. https://doi.org/10.2307/3150980

Ghosh, D., \& Gurunathan, L. (2015). Job Embeddedness: A Ten-year Literature Review and Proposed Guidelines. Global Business Review, 16(5), 856-866. https://doi.org/10.1177/0972150915591652

Hair, J. F., Ringle, C. M., \& Sarstedt, M. (2011). PLS-SEM: Indeed a Silver Bullet. Journal of Marketing Theory and Practice, 19(2), 139-152. https://doi.org/10.2753/MTP1069-6679190202

Hair Jr, J., Sarstedt, M., Hopkins, L., \& G. Kuppelwieser, V. (2014). Partial least squares structural equation modeling (PLS-SEM). European Business Review (Vol. 26). https://doi.org/10.1108/EBR-10-2013-0128

Hair, J.F., Hult, G.T.M., Ringle, C.M. and Sarstedt, M. (2014). A Primer on Partial Least Squares StructuralEquation Modeling (PLS-SEM). Sage, Thousand Oaks. https://doi.org/10.1108/EBR-10-2013-0128

Hair, J., Black, W., Babin, B., Anderson, R., \& Tatham, R. . (2006). Multivariate data analysis: A global perspective. San Francisco, New York. https://doi.org/10.1007/978-94-009-3789-5

Hair, J. F., Sarstedt, M., Pieper, T. M., \& Ringle, C. M. (2012). The Use of Partial Least Squares Structural Equation Modeling in Strategic Management Research: A Review of Past Practices and Recommendations for Future Applications. Long Range Planning, 45(5-6), 320-340. https://doi.org/10.1016/j.lrp.2012.09.008

Halbesleben, J. R. B., \& Wheeler, A. R. (2008). The relative roles of engagement and embeddedness in predicting job performance and intention to leave. Work and Stress, 22(3), $242-256$. https://doi.org/10.1080/02678370802383962

Henseler, J., Ringle, C. M., \& Sarstedt, M. (2014). A new criterion for assessing discriminant validity in variance-based structural equation modeling. Journal of the Academy of Marketing Science, 43(1), 115-135. https://doi.org/10.1007/s11747-014-0403-8

Khan, R., Naseem, A., \& Masood, S. A. (2019). Effect of Continuance Commitment and Organizational Cynicism on Employee Satisfaction in Engineering Organizations. International Journal of Innovation, Management and Technology, 7(4), 141-146. https://doi.org/10.18178/ijimt.2016.7.4.661

Koen, V., Asada, H., Nixon, S., \& Rahuman, M. (2017). Malaysia’s economic success story and challenges.

Latif, A., Delaila, F., \& Saraih, U. (2016). Factors Influencing Employee Turnover in Private Sector in Malaysia: A Concept Paper.

Lee, T. W., Burch, T., \& Mitchell, T. R. (2014). The Story of Why We Stay: A Review of Job Embeddedness. Ssrn, 199218. https://doi.org/10.1146/annurev-orgpsych-031413-091244

Lee, T. W., Mitchell, T. R., Sablynski, C. J., Burton, J. P., \& Holtom, B. C. (2004). The effects of job embeddedness on organizational citizenship, job performance, volitional absences, and voluntary turnover. Academy of Management Journal, 47(5), 711-722. https://doi.org/10.2307/20159613

Mitchell, T. R., Holtom, B. C., Lee, T. W., Sablynski, C. J., \& Erez, M. (2001). Why People Stay: Using Job Embeddedness to Predict Voluntary Turnover. Academy of Management Journal, 44(6), 1102-1121. https://doi.org/10.5465/3069391

Mitchell, T. R., \& Lee, T. W. (2001). Voluntaryturnoverandjob Embeddedness : Foundations Foracomprehensivetheory Ofattachment. Research in Organization Behavior, 33, 189-246.

Naim, M. F., \& Lenka, U. (2017). Mentoring, social media, and Gen Y employees' intention to stay: towards a conceptual model. International Journal of Business and Systems Research, 11(1/2), 28. https://doi.org/10.1504/IJBSR.2017.080832

Naim, M. F., \& Lenka, U. (2016). Knowledge sharing as an intervention for Gen Y employees' intention to stay. Industrial and Commercial Training, 48(3), 142-148. https://doi.org/10.1108/ICT-01-2015-0011

Ngoc, N., Phuong, D., Chi, H., \& City, M. (2018). Key Determinants And Effect Of Organizational Commitment On Employee' S Intention To Stay : A Pls-Sem, (September). https://doi.org/10.7456/1080SSE/171 
Noor, A., Zainuddin, Y., Panigrahi, S. K., \& Rahim, F. binti T. (2018). Investigating the Relationship among Fit Organization, Organization Commitment and Employee's Intention to Stay: Malaysian Context. Global Business Review. https://doi.org/10.1177/0972150918755896

Omar, S. (2018). The Influence of Career Adaptability and Work Happiness on ICT Professionals' Intention to Leave. International Journal of Human Capital and Information Technology Professionals, 9(1), 23-36. https://doi.org/10.4018/IJHCITP.2018010102

PLS-SEM. (2015). Discriminant Validity : Check Out How To Use The New HTMT Criterion!

Radford 2013-2016; Global salary increase and turnover 2015.

Ramayah, T., Cheah, J., Chuah, F., Ting, H., \& Memon, M. A. (2018). Partial Least Squares Structural Equation Modeling (PLS-SEM) using SmartPLS 3.0 (2nd Edition). Pearson Malaysia Sdn Bhd. https://doi.org/10.1080/09585192.2017.1416655

Treuren, G. (2009). Does off-the-job embeddedness matter in predicting intention to leave?, 1-25. Retrieved from http://search.ror.unisa.edu.au/record/UNISA_ALMA11143324640001831/media/digital/open/9915910969101 831/12143324630001831/13143321870001831/pdf

Treuren, G. J. M., \& Fein, E. C. (2018). Off-the-job embeddedness as a moderator of the relationship between work and life conflict and turnover intention. International Journal of Human Resource Management, 0(0), 1-22. https://doi.org/10.1080/09585192.2018.1510847

Umoh, G. I., Amah, E., \& Wokocha, I. H. (2014). Employee Benefits and Continuance Commitment in the Nigerian Manufacturing Industry. IOSR Journal of Business and Management Ver. II, 16(2), 69-74. Retrieved from www.iosrjournals.org

Vandenberghe, C., Panaccio, A., \& Ben Ayed, A. K. (2011). Continuance commitment and turnover: Examining the moderating role of negative affectivity and risk aversion. Journal of Occupational and Organizational Psychology, 84(2), 403-424. https://doi.org/10.1348/096317910X491848

Woon, W., Tan, C., \& A. N.-G. B., \& 2017, undefined. (n.d.). Linking Organizational Climate, Psychological Ownership, and Intention to Stay: A Proposed Model. Search.ebscohost.com.

Youcef, S., Ahmed, S. S., \& Ahmed, B. (2016). The Impact of Job Satisfaction on Turnover Intention by the Existence of Organizational Commitment, and Intent to Stay as Intermediates Variables Using approach PLS in Sample Worker Department of Transport Saida. Management, 6(6), $198-202$. https://doi.org/10.5923/j.mm.20160606.03 